\title{
Environmental politics in the 2015 Danish general election
}

Kosiara-Pedersen, Karina; Little, Conor

Published in:

Environmental Politics

Publication date:

2016

Document version

Other version

Citation for published version (APA):

Kosiara-Pedersen, K., \& Little, C. (2016). Environmental politics in the 2015 Danish general election. Environmental Politics, 25(3), 558-563. 


\section{PROFILE}

\section{Environmental politics in the 2015 Danish general election}

Karina Kosiara-Pedersen and Conor Little, University of Copenhagen

Word count: 1,942

This is an Accepted Manuscript of an election report first published by Taylor \& Francis on 15 December 2015, available online:

http://www.tandfonline.com/doi/full/10.1080/09644016.2015.1123825

Full citation: Kosiara-Pedersen, K. and Little, C., 2016. Environmental politics in the 2015 Danish general election. Environmental Politics, 25 (3), 558-563. 


\title{
PROFILE
}

\section{Environmental politics in the 2015 Danish general election}

\author{
Karina Kosiara-Pedersen and Conor Little
}

After ten years of right-of-centre, Liberal Party-led governments, the Social Democrats took office in 2011 in coalition with the Social Liberals and the Socialist People's Party, and with the support of the Red-Green Alliance. With the next election due no later than 14 September 2015, Prime Minister Helle Thorning-Schmidt's New Year's speech signalled new spending on social services and restrictions on immigration. Poster campaigns and a series of economic stimulus packages followed. Two shootings in Copenhagen in February, carried out by a young Muslim man, focussed further attention on immigration, integration, and security. The election was called on 27 May, followed by an intensive campaign that culminated with polling on 18 June.

\section{Context}

Environmental issues have a relatively high priority in Danish public opinion compared to other EU countries (European Commission 2015), although fewer than one in ten Danes indicate that the environment is the most important issue (Stubager et al. 2013). In late 2014 and early 2015, concern about the environment reached levels not seen since the 2007 general election and the 2009 UN Climate Summit in Copenhagen. However, concern about other issues, especially immigration, rose even more sharply (Figure 1). 


\section{$<<<$ FIGURE 1 ABOUT HERE $>>>$}

Thorning-Schmidt's governments (2011-2015) developed some important environmental and climate policies, setting a target of a $40 \%$ greenhouse gas emissions reduction for 2020, and in 2012 adopting an ambitious energy policy that envisaged decarbonisation of the Danish energy system by 2050. Although the Liberal Party (Venstre) resisted parts of the energy package, especially environmental taxation increases, the government ultimately received broad support from the main opposition parties and from peak business organizations. Notable exceptions included the small Liberal Alliance party and agricultural interests. The government took a strong position on EU negotiations for the 2030 climate and energy package, with successive Social Liberal Climate Ministers criticizing the European Commission's proposal, including its lack of binding nationallevel renewable energy targets. In 2014, left-of-centre parties and the Conservatives supported the government's enactment of climate legislation that established an independent Climate Council and a mechanism for regular revisions of emissions targets.

Despite political consensus on some important elements of climate and energy policy, which has yielded considerable gains (43\% of electricity produced in 2014 was generated by wind), the perceived competence of the left-of-centre parties on environmental protection has been consistently and substantially higher than that of the right-of-centre parties (Stubager et al. 2013). Left-right differences on climate policy were reflected in the main parties' election manifestos in 2015 and in sectoral policy positions, such as the Liberal Party favouring road-building over the government's focus on rail.

Green parties (and green parties): something old, something new... 
The Danish 'Green party' (De Gronne) stood for election in 1987, 1988 and 1990 but never gained representation as green issues were 'owned' by the Socialist People's Party and the Social-Liberals. Therefore, the identification of green parties in Denmark has not been entirely straightforward and was even less so in 2015.

Although not 'Green' by name, the Socialist People's Party has been in many respects a traditional Green party, with a participatory and egalitarian culture and astrong emphasis on environmental policies. After its MEP joined the Greens-EFA group in the European Parliament in 2004, the party followed, becoming an Observer Party in the European Greens and ultimately a full member. Having run a joint campaign with the Social Democrats in 2011, the party joined government for the first time in 2011, obtaining six ministerial positions (of 23), despite a significant reduction in its vote share.

Its time in government was marked by conflict with its coalition partners, including on environmental issues such as road pricing in Copenhagen, and pressure from the government's support party, the Red-Green Alliance, on a wide range of welfare and economic policies. In 2012, a settlement on taxation policy caused a sharp conflict between the government and the Red-Green Alliance which, in conjunction with poor opinion polls, led to a crisis for the Socialist People's Party. Its leader Villy Søvndal resigned for health reasons and was replaced by Annette Vilhelmsen, representing the party's left wing, who was then appointed to a ministerial position. This prompted the resignation and defection to the Social Democrats of several prominent members.

In 2013, further conflict with the Red-Green Alliance and within the government parties occurred on welfare reforms, tax reforms, and the 2014 budget. The Socialist People's Party experienced a significant setback at the local elections in November 2013, losing almost two-thirds of its vote. In January 2014, it left the government, citing its opposition to plans to sell $18 \%$ of a state-owned 
energy company, Danish Oil and Natural Gas (DONG), to Goldman Sachs, and to giving them a veto over some management decisions, a policy that was opposed by a majority of Danes. At the same time, party leader Vilhelmsen stepped down and more officeholders resigned and defected to the Social Democrats and Social Liberals. The party continued to support the government in parliament and former Transport Minister Pia Olsen Dyhr was elected as the party's new leader, a position she retained after the general election.

A new party with a strong claim to green credentials, The Alternative, was founded in November 2013 by Uffe Elbæk. He had been Social Liberal Minister for Cultural Affairs (2011-2012) but resigned due to accusations of nepotism, which ultimately were shown to be false. The new party, authorised to stand for election in March 2015, has environmental sustainability permeating all legislation as its main goal, with its policies including a 30-hour working week and meat-free days. Like traditional Green parties, it wants to alter how politics is conducted.

Three other parties are in some respects 'green'. The Social Liberals have had a distinct, centrallypositioned green image, but this was less pronounced in 2011-2015 due to their focus on the economic agenda. The only party with 'Green' in its name - the Red-Green Alliance - has consistently been perceived by voters as the greenest party (Stubager et al. 2013). With some of the characteristics of traditional Green parties, including a high level of grassroots democracy and principles of rotation, the party has persistently pursued environmental policies, but has a predominantly left-socialist profile. Approaching the 2015 election, with a popular political spokesperson, it fared well in the polls due to dissatisfaction with the government parties. Finally, the Conservative People's Party is not a green party in the traditional sense, but it has on several occasions tried to develop an image of being the green party right-of-centre, and has supported stronger climate policies, something that has been driven in the past by the popular Connie 
Hedegaard, former Minister of the Climate and Energy (2007-2009) and EU Climate Commissioner (2010-2015).

\section{Results}

When the election was called, the parties supporting the incumbent government were behind in the opinion polls, but they increased their support up to the halfway mark of the campaign. The opposition parties took the lead in the second half of the campaign, but approaching election day both sides converged on 50 percent, which was borne out by the results. Despite his own party losing a quarter of its voters and winning only 34 seats, the Liberal Party's candidate for Prime Minister, Lars Løkke Rasmussen, received the support of the bare minimum of 90 MPs to form the first single-party minority government since 1982(Table 1).

\section{$<<<$ TABLE 1 ABOUT HERE $>>>$}

The Alternative fared much better than expected, winning nine seats and outperforming a number of established parties., They attracted voters from the urban, well-educated 'creative classes' , thus competing mostly with the Social Liberals and other parties in the left-of-centre bloc. The RedGreen Alliance was also successful. In 2011 it had tripled its representation to 12 seats, and in 2015 increased it further to 14 . Both the smaller parties that had been in government - the Social Liberals and Socialist People's Party - lost support. 


\section{Environmental policy and politics after the 2015 election}

Overall, the environment seems to have lost in the 2015 election: the new government is much less concerned about environmental issues and in its first months it rolled back several environmental initiatives of the previous government. Environmental policy did not have any significance in the government coalition negotiation period. The government programme does not include environmental concerns in its list of the nine highest priorities, but they are mentioned in one of fifteen sections under the heading 'Green transition with ambitions and realism', which identifies major goals as working for ambitious targets within the EU and a Denmark independent of fossil fuels by 2050. It frames the creation of growth, jobs, and welfare as a 'precondition' for 'passing nature and the environment on to the coming generations'.

Furthermore, the government's reconfiguration of ministries indicates that environment policy has been downgraded. The agriculture and environment ministries were merged, which seems to have favoured the new ministry's agriculture policy functions. A new section of the department was established to monitor 'overimplementation' of EU directives on the environment and one of the new minister's early actions was to ask the EU Commission for more latitude for Danish farmers in spreading slurry.

Nonetheless, since several parties lay claim to 'green' credentials, environmental politics in Denmark appears to have a robust electoral base that can survive difficult periods such as that experienced by the Socialist People's Party in government. It remains to be seen whether the new party, The Alternative, can demonstrate to its voters that they can make a difference in parliamentary policy negotiations and whether it can compete with like-minded parties that have now joined it in opposition. Likewise, the Red-Green Alliance will face stiffer competition for 
protest votes now that other left-of-centre parties are also in opposition and can therefore act with greater autonomy.

As for these parties' chances on promoting environmental concerns, that may depend on whether the government is interested in building support in parliament across the left-right divide or whether it wants to draw its support from not-so-environmentally friendly parties on the right. Nonetheless, there is one hope for creating a 'green majority' without the government. The Conservatives' electoral loss in 2015 has again directed their attention to a 'green' approach and they claim that they are ready to pursue environmental legislation without the consent of the Liberal Party. It remains to be seen whether Lars Løkke Rasmussen, a master negotiator and deal-maker, is able to tie their hands. 


\section{References}

European Commission, 2015. European Commission - Public Opinion [online]. European

Commission. Available from: http://ec.europa.eu/public_opinion/cf/index.cfm?lang=en [Accessed 9 Nov 2015].

Stubager, R., Holm, J., Smidstrup, M., and Kramb, K., 2013. Danske vælgere 1971-2011. En oversigt over udviklingen i vælgernes holdninger mv. 
Figure 1. The two most important issues facing Denmark: mentions of the environment, the economic situation and immigration, November 2003 - May 2015

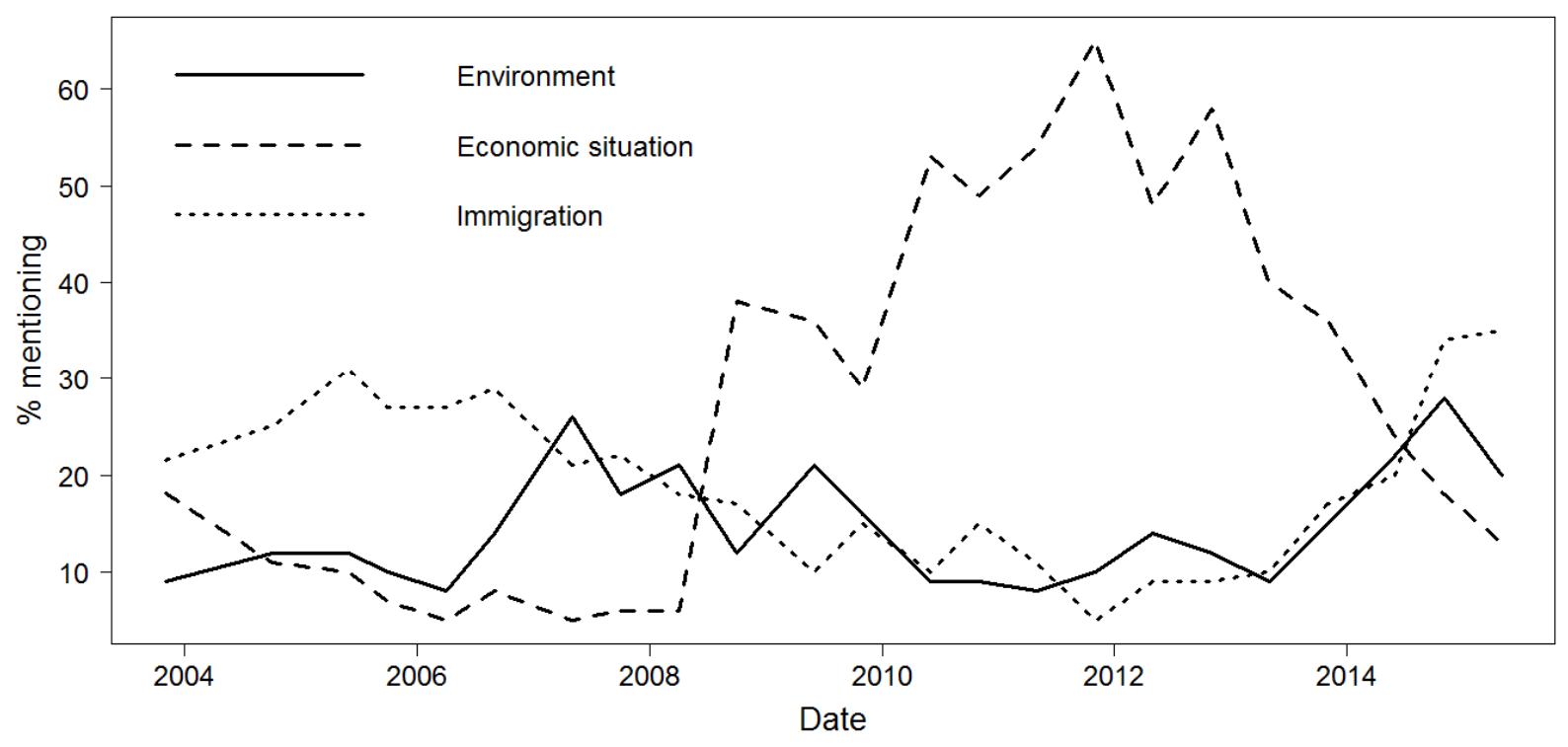

What do you think are the two most important issues facing Denmark at the moment? (max. 2 answers possible). Source: Eurobarometer. 
Table 1. Elections to the Danish Folketing on June $18^{\text {th }} 2015$

\begin{tabular}{|c|c|c|c|c|}
\hline & $\begin{array}{c}\text { Seats } \\
\mathrm{N}\end{array}$ & $\begin{array}{c}\text { Votes } \\
\%\end{array}$ & $\begin{array}{l}\text { Vote } \\
\text { share } \\
\text { change } \\
\text { pct. pt. }\end{array}$ & Position \\
\hline Social Democrats [Socialdemokraterne] & 47 & 26.3 & +1.5 & $1 \mathrm{st}$ \\
\hline $\begin{array}{l}\text { Red-Green Alliance [Enhedslisten - de rød- } \\
\text { grønne] }\end{array}$ & 14 & 7.8 & +1.1 & 4 th \\
\hline Alternative [Alternativet] & 9 & 4.8 & +4.8 & 6 th \\
\hline Social Liberal Party [Radikale Venstre] & 8 & 4.6 & -4.9 & 7 th \\
\hline Socialist People's Party [Socialistisk Folkeparti] & 7 & 4.2 & -5.0 & 8 th \\
\hline Total: pro left-of-centre PM & 85 & 47.7 & & \\
\hline Danish People's Party [Dansk Folkeparti] & 37 & 21.1 & +8.8 & 2 nd \\
\hline Liberal Party [Venstre] & 34 & 19.5 & -7.2 & $3 \mathrm{rd}$ \\
\hline Liberal Alliance [Liberal Alliance] & 13 & 7.5 & +2.5 & 5 th \\
\hline Conservatives [Det Konservative Folkeparti] & 6 & 3.4 & -1.5 & 9th \\
\hline Christian Democrats [Kristendemokraterne] & 0 & 0.8 & 0 & 10th \\
\hline Total: pro right-of-centre $P M$ & 90 & 52.3 & & \\
\hline Total & 175 & 100 & & \\
\hline
\end{tabular}

Note: The popular vote and four MPs elected from the self-governing areas of Greenland and Faroe Islands are not included. Source: The Electoral Office of the Ministry of the Interior (2015). 